\title{
Hans Eysenck: Personality Theorist
}

\author{
William Revelle \\ Northwestern University, Evanston, IL
}

Email: William Revelle revelle@ northwestern.edu 


\begin{abstract}
Hans Eysenck was the leading personality and individual differences theorist of the 20th century. His goal was to combine the best theories and practices of experimental psychology with the best measurement techniques of individual differences. From his earliest analyses of the dimensions of individual differences, through multiple iterations at theory building to his lasting achievements in building a paradigm for personality research he left a legacy of broad and rigorous research. He strove to integrate behaviour genetics, psychophysiology, cognitive psychology, aesthetics, and psychometrics into a unified theory of personality and individual differences. Although best known for his biological theory of extraversion, his impact upon the field was much more than that and can not be summarized in a brief article. I review his major theoretical contributions and relate them to modern personality theory and show how his many contributions continue to shape current personality research.
\end{abstract}

Keywords: Hans Eysenck, Personality Theory, Experimental Psychology, Psychometrics, Learning Theory, Arousal Theory, Intelligence, Biological Basis of Personality, motivation, goals 
Personality theory of the mid-to-late twentieth century was dominated by the contributions of three very different people: Gordon Allport, Raymond Cattell and Hans Eysenck. It is the contributions of Eysenck that are the focus of this special issue, but it is worth considering his work in the context of the broader field defined by the other two giants. For all three laid the broad foundations for much of current research in personality and individual differences.

Gordon Allport (November 11, 1897-October 9, 1967) is perhaps best known to personality psychologists for his basic text on personality (Allport, 1937) as well as his classic listing of the 17,953 words associated with personality in the English lexicon, of which 4,504 provided "a minimum list of trait names" (p. 26, Allport \& Odbert, 1936). This list, seen as extension of the original lexical hypothesis of Galton (1884), influenced much of the early "Big 5" measures of personality as exemplified in the work of Warren Norman (1967), Lewis Goldberg (1992) and Willlem Hofstee and Boele de Raad (Hofstee, de Raad \& Goldberg, 1992). The lexical hypothesis continues to shape the research of Ashton and Lee (2005a), Ashton and Lee (2005b), Ashton, Lee and Goldberg (2007), Hofstee, Kiers, de Raad, Goldberg and Ostendorf (1997) and Saucier (2009). Allport was also influential in his emphasis upon 'idiographic' rather than 'nomothetic' approaches to personality. Treating each individual as unique continues to appeal to those psychologists involved in treatment or those who prefer to study one's 'life story' (McAdams, 2008).

Raymond Cattell (March 20, 1905-February 2, 1998) was 11 years older than Eysenck (March 4, 1916-September, 4, 1997) and outlived Eysenck by five months. Both Cattell and Eysenck studied at the University of London and both were influenced by the great psychometricians Charles Spearman and Cyril Burt. Throughout their long careers, Cattell and 
Eysenck showed the power and possibility of mathematical and scientific approaches to the study of personality, ability, and individual differences broadly conceived.

Cattell built upon the lexical studies of Allport and Odbert (1936) and the factor analytic techniques originally developed by Spearman (1904) and Thurstone $(1933,1935)$ to develop a broad based descriptive theory of personality (Cattell, 1943, 1946a,b,c). The paragraph descriptors in Cattell (1946b) formed the basis of the peer rating studies reported by Tupes and Christal (1961) and then used by Norman (1963) in what might be seen as the first five-factor paper. Among his (at least) 43 books and 500 articles are contributions that include fundamental development in psychometrics (Cattell, 1966a,b, 1978), in the measurement of intelligence (Cattell, 1963; Horn \& Cattell, 1966), and some very fundamental work in behaviour genetics. Given Cattell's interest in multivariate approaches to individual differences, it was not surprising that he was the founder of the Society for Multivariate Experimental Psychology (SMEP), an organization that allows free flowing exchange and debate between quantitatively oriented personality researchers with their more purely psychometric brethren. Its journal, Multivariate Behavioral Research has become one of the top journals in quantitative psychology.

Eysenck was the youngest of these three personality leaders but had the greatest impact on the current field of personality and individual differences. For he took the study of individual differences beyond description to attempts at causal theories. He attempted to marry the best theories of experimental psychology with the best psychometrics of individual differences. As general psychological theory developed, so did his theories of personality. As was Cattell, Eysenck was amazingly prolific, credited with at least $80-100$ books and more than 1,600 articles

His early work was not so much developing causal theories as developing descriptive taxonomies. He explicitly rejected Allport's idiographic approach and searched for general laws 
- in his discussion of Allport's emphasis upon the uniqueness of personality he humorously commented that "It is quite undeniably true that Professor Windelband is absolutely unique. So is my old shoe" (Eysenck, 1952, p. 18). Thus, his early books reported on how myriad individual differences could be organized into a limited number of dimensions (Eysenck, 1947; Eysenck, 1952). To him, science was not just collecting facts, it was the organization of those facts into testable hypotheses.

He considered theory as a cumulative exercise, starting at observation, developing hunches, elaborating these into testable hypotheses, integrating hypotheses into falsifiable theories with the hope of eventually developing lawful descriptions of personality (Eysenck \& Eysenck, 1985). His critical approach to psychological theory and his emphasis upon paradigmatic research inspired the many scientists who joined the society that he founded, the International Society for the Study of Individual Differences (ISSID). Eysenck was the founding editor of ISSID's journal, Personality and Individual Differences, which continues in his tradition of publishing exciting, sometimes controversial, but always rigorous studies of individual differences. As an editor of PAID he was happy to accept articles critical of his theories, for he believed that the process of science was one of winnowing the good from the bad. To Eysenck, theories were meant to be tested; they were meant to be improved.

\section{Dimensions of Personality}

As a German national studying and then receiving his Ph.D. in the United Kingdom during the Second World War, Eysenck was not allowed to join the Royal Air Force or other military branch and after a brief stint spotting airplanes with the Air Raid Precautions Service, he was appointed to the position of research officer at the Mill Hill Emergency Hospital (on the outer reaches of north London). (Eysenck reported that his colleagues in the Air Raid 
Precautions Service assumed from his obvious foreign accent that he was Welsh and therefore relatively acceptable!) The Mill Hill experience led to his first major book, Dimensions of Personality (Eysenck, 1947) which introduced his fundamental dimensional analysis of personality as representing Neuroticism-Stability and Introversion-Extraversion. His subjects were 700 soldiers admitted to Mill Hill on the recommendation of a psychiatrist and all had primarily neurotic symptomatology. What makes the study so unusual was that the data were not the standard personality questionnaires used by others, but rather actual behaviour or behavioural ratings on a psychiatrists intake rating scale. That is, the variables included age, employment status, type of job (skilled versus unskilled), psychological abnormality of parents or siblings, level of alcohol consumption, etc. (Table 1, p. 853, Eysenck, 1944).

Given that the current consensual dimensions of the "The Big 5" are based upon Galton's lexical hypothesis (Galton, 1884) and the structure of adjectives (Goldberg, 1992) from self report or peer ratings and that the "Five Factor Model" (McCrae \& Costa, 2008) comes from the structure of self reported responses to short sentence fragments, it is easy to forget that the fundamental descriptions of Neuroticism-Stability and Introversion-Extraversion from Eysenck (1947) were based on an analysis of actual behaviour. That is, these dimensions were not just how people described themselves, nor how others described them, but how people behave - a statistically pleasing feature of these ratings is that they were aggregated over multiple occasions. That the factor loadings on the first factor of these behavioural measures were strongly correlated with psychiatric ratings of neuroticism gave credence to the identification of the neuroticism dimension. Equating this dimension with Wundt's dimension of excitability, it was reasonable to equate the second dimension with that of Wundt's changeability. (Wundt, 1897, postulated these two dimensions to account for the four types of Hippocrates and Galen). 
This volume showed the quintessential Eysenck for it was an attempt to integrate experimental psychological phenomena such as salivary output, night vision, and suggestibility with individual differences in the factor structure of the clinicians rating scale. This theme, of integrating experimental with correlational techniques, would be central to much of Eysenck's later writings (e.g., Eysenck, 1966, 1988, 1997; Eysenck \& Eysenck, 1985).

\section{The Scientific Study of Personality}

In a follow on to Dimensions of Personality the Scientific Study of Personality (Eysenck, 1952) tried to make the study of personality respectable to experimental psychologists. Thus, Eysenck adopted the language of the null hypothesis and operational definitions of his phenomena. Although quaint to those brought up thinking of latent variables, hypothetical constructs, and Bayesian analysis, this was written in the best spirit of behaviourism: "the subject matter of a science of personality must be human behaviour" (Eysenck, 1952, p. 37). Thus, he wanted to show that self report questionnaires (the Maudsley Medical Questionnaire, a precursor the Maudsley Personality Inventory (Eysenck, 1959) and eventually the Eysenck Personality Inventory (Eysenck \& Eysenck, 1964) and its successors could in fact be shown to relate to the incidence or risk of neurotic diagnoses and psychiatric breakdown.

Following a brief introduction to the methodology of factor analysis, he considered its use in measuring personality constructs. Contrasting the long history of the factor analysis of cognitive abilities (Spearman, 1904; Thurstone, 1935) with that of non-cognitive studies using self report and ratings, Eysenck discussed the arbitrariness of factor rotation procedures and advocated the use of "criterion rotations". That is, rather than search for simple structure in the self report or peer ratings of Cattell (1946a), Eysenck suggested rotating to specific external criteria. This "criterion analysis" might use diagnoses of neuroticism as defining one axis in the 
factor analytic solution to the structure of various behavioural measures that would have no obvious relationship to neuroticism (e.g., manual dexterity, personal tempo, speeded performance, persistence holding a leg in the air, etc.). The subsequent factors would be orthogonal to this criterion. Although other, automatic, rotation criteria were developed later (Browne, 2001; Carroll, 1953; Kaiser, 1958) Eysenck's emphasis upon rotating factors to externally meaningful solutions should not be forgotten for it gives a sense of the validity of what are otherwise (useful) mathematical fictions (Revelle, 1983).

Perhaps completely obvious to many modern clinicians and researchers, Eysenck's "dimensional hypothesis" that psychopathological diagnoses were merely extreme values of normal personality dimensions (Eysenck, 1952) was a break from the categorical diagnoses of psychopathology of the time. If dimensional, then scores on his measure should show monotonic relationships with criteria that distinguish neurotic patients from controls. If categorical, then the scores should show no such relationship within diagnostic groups. Similar arguments have been made by Grayson (1987) who shows that even bimodal distributions do not imply types. The types versus dimensions debate continues, with some (e.g., Meehl, 1992; Waller, 2006) making a strong case for a taxometric approach and proposing a number of useful algorithms for detecting taxons (Cole, 2004). Indeed, as Meehl (1992, p. 121) put it: "There are chipmunks and gophers, there are no gophmunks." Useful overviews of the taxometric versus dimensional approach include Ruscio and Ruscio $(2000,2008)$ and an interesting demonstration that except for a few physical measures, indices showing sex differences are best described as dimensional rather than taxonomic (Carothers \& Reis, 2013). Perhaps the most powerful demonstration of the power of dimensional thinking about personality disorders is the work by Krueger and his colleagues (Krueger \& Finger, 2001; Krueger, 2002; Krueger \& Markon, 2006; Markon, Krueger \& 
Watson, 2005), who found they could organize the set of comorbidities between the various personality disorders in terms of two dimensions: externalizing and internalizing. Their findings are in surprising agreement with the dimensional analysis reported in Eysenck (1952).

Anticipating by twenty years the evidence for the heritability of broad personality traits (Bouchard, 1994; Loehlin, 1965, 1992; McGue \& Bouchard, 1998; Tellegen et al., 1988), Eysenck (1952) analyzes not just single measures, but rather the heritability of factor scores. He rejected the environmental zeitgeist and demonstrated that parental influences on their children are just as likely to be genetically as environmentally driven.

\section{The Dynamics of Anxiety and Hysteria}

Moving from the descriptive taxonomies of his earlier work, Eysenck (1957) attempted to explain introversion-extraversion and neuroticism-stability in terms of the parameters of what were then the dominant theories of learning (Hull, 1943, 1952; Spence, Farber \& McFann, 1956). The results were controversial, as some labs found anxiety related to eye-blink conditioning, but not for extraversion, while those working with Eysenck found that introverts conditioned better than extraverts, but that there were no differences related to anxiety. Years later, Eysenck (1984) in a critique of mindless meta-analysis, recounted how Gregory Kimble had visited both the Spence and Eysenck labs in an attempt to understand the reason for their different pattern of results. It was clear to Kimble that Spence emphasized making his subjects anxious while Eysenck's researchers worked hard to make their subjects relaxed. This result is important to remember when discussing the problem of replicability across labs, for we rarely report on the background variables of our studies, but rather emphasize our experimental manipulations. That we are normally nice or nasty to our participants is not part of the research protocol, nor is the fact that a train goes by every minute and we do not have a sound attenuating 
chamber. We report what we do to our participants as a function of our research design, not the normal situation. In support of the specificity of conditioning results, studies by Levey and Martin (1981) showed that eye-blink conditioning depended upon the arousal properties of the situation.

\section{The Biological Basis of Personality}

The late 1960 s to early 1980 s were a dark time for personality researchers in the United States. We were told that personality was a fiction and all in the mind of the beholder. If there was anything to personality, it produced correlations no bigger than .3 (which became known as the "personality coefficient"). Our students could not get jobs; we were asked why we continued in such a useless field. It was not until the $F$ s and $t$ s of experimentalists were expressed in effect size and correlational units and seen to be even smaller than .3 that this particular criticism was

dropped. Some of us think back to these years as the "dark ages of personality" (Revelle, Wilt \& Condon, 2011). Luckily, this was not true in Europe, where personality research was alive and well. Indeed, in 1967 Eysenck produced a monumental review of the biological correlates of personality and proposed a theory of the relationships between physiological arousal, self reported individual differences and a variety of measures of performance (Eysenck, 1967). This work was in the scientific approach proposed by Cronbach (1957), Eysenck (1966) and Vale and Vale (1969) to unify the two disciplines of scientific psychology: the correlational and the experimental.

\subsection{Arousal: a useful construct}

In experimental psychology in the early 50 s to the late 60 s, the hypothetical construct of arousal was inspired by the writings of Duffy (1951, 1962); Hebb (1955) and Malmo (1959) as a general, diffuse and non-specific state of activation. Duffy (1951) distinguished between the 
directional and the energy mobilization functions of emotions. Hebb (1955) related arousal to the non-specific activation discussed by Lindsley (1951). The construct of arousal was used in experimental psychology to unify the disparate effects of noise, sleep deprivation, time on task, diurnal rhythms, and alcohol (Broadbent, 1971). Arousal was, unfortunately, more complicated than originally hoped. In a thoughtful critique of the construct and its measurement, (Lacey, 1967, p. 15) distinguished between arousal of the hand, the heart, and the head and suggested that: "electrocortical arousal, autonomic arousal, and behavioural arousal may be considered to be different forms of arousal, each complex in itself." In terms of self report, arousal turned out to be at least two dimensional, with the alertness-sleepy dimension independent from a tension-calm dimension (Thayer, 1970, 1978). Other useful measures of arousal included those physiological measures subsequently reviewed by Stelmack (1990) and Stelmack and Wilson (1982).

\subsection{Personality, arousal and preferential choice}

Eysenck took the concept of arousal and integrated it with his dimensions of individual differences. Some earlier hints that introversion was related to arousal came from the studies of Colquhoun \& Corcoran (1964) and Corcoran (1965) who had noticed the parallelism of introversion to arousal manipulations and used introversion as a way of varying the presumed level of arousal. In addition, Gordon Claridge (1967) (see also, Claridge \& Herrington, 1960) had explored the relationship of the sedation threshold to personality (lower levels of barbiturate led to slurred speech and more frequent mistakes in doubling digits for non-neurotic extraverts compared to non-neurotic introverts) and interpreted these findings in terms of arousal. Eysenck reviewed these studies and many others to support the claim that introverts were more aroused than extraverts and that these differences subsequently led to behavioural differences ${ }^{1}$. This was 
based upon an amalgam of diverse studies ranging from resting frequency of the EEG to increased salivation in response to the taste of lemon juice (Corcoran, 1964). Another study frequently cited by Eysenck was Shigehisa and Symons (1973) who examined multi-modal sensitivity. That is, all subjects showed a U-shaped relationship between auditory thresholds and light intensity with the minimum threshold at lower levels of light intensity for introverted subjects than for extraverts. Many other studies showed a presumed higher level of arousal for introverts but the results were typically complicated and sometimes depended very much upon the experimental conditions. Gale (1981), for instance, reviewing much of the EEG and extraversion literature reported that the effect was there, but only for mid range of arousal conditions

Arousal was also used as an explanatory construct in the theory of preferences for complexity (Berlyne, 1960). Adapting an earlier proposal by Wundt $(1874,1904)$ that the preferred hedonic state was an inverted U function of stimulus intensity (a 'Goldilocks' relationship, such that the most preferred level of stimulation was not too much, and not too little) Berlyne (1960) proposed that small changes in arousal were more hedonic and that the optimal level was a small decrease or small increase in arousal. Eysenck (1967), combining the evidence for introversion-extraversion differences in arousal, and Wundt's curve of hedonic tone as a function of stimulation intensity, proposed that introversion was related to stimulation preference. If introverts were more internally aroused, then less external stimulation would be required for them to achieve their maximal hedonic level than would be the case of the less aroused extraverts. Classic demonstrations of these effects included individual differences in sensitivity to pain (Haslam, 1967; Petrie, Collins \& Solomon, 1960), and the preferred level of background noise among children (Elliott, 1971). Extraversion was highly correlated with 
stimulation seeking (Farley \& Farley, 1967, 1970).

This theory of arousal, introversion, and preferential choice made good intuitive sense, for it could explain the use of drugs to change preferential choice (barbiturates made introverts prefer more complex shapes Bartol, 1975) as well as the observation that one would increase ones's arousal through self administration of caffeine if required to do an introverted task (study at a library) or decrease it through the use of alcohol if required to do an extraverted task (go to a lively party). It could also be used to explain the 'paradoxical' effect of amphetamines given to hyper active children. Stimulants were found to calm down hyperactive (extraverted?) children. Their hyperactivity could be seen as a consequence of being under-aroused and thus seeking stimulation. The administration of stimulants thus could be construed as bringing them up to their preferred level of arousal.

There was one finding, however, that although it did show biological correlates of introversion-extraversion, was problematic for the arousal theory. This was the observation that introverts and extraverts differed in the phase of their natural diurnal rhythm as indexed by body temperature (Blake, 1967). Although the implications of this study were not recognized for several years, it was an early finding that was logically inconsistent with the hypothesis that there were trait differences in arousal. If body temperature is a legitimate index of arousal, then introverts were more aroused, yes, but just in the first part of the day and extraverts had higher body temperatures late in the day. That is, arousal level was just a state variable, not a trait consistent across the day. The implications of arousal as a state variable was that introverts should seek out more stimulation (go to lively parties) in the evening while extraverts, least aroused early in the morning, should be seeking arousal by partying in the morning.

\subsection{Personality, arousal, and performance}


In addition, to make things even more complicated, the effects of arousal upon performance were thought to be non-monotonic and to depend upon task difficulty. Frequently cited was the study by Yerkes and Dodson (1908) on 38 "dancing mice" which showed that learning to criterion in a discrimination task was a curvilinear function of the level of electric shock and of discrimination difficulty. Although originally just a study of learning, the Yerkes-Dodson effect came to be generalized to a theory of motivation and performance (Broadhurst, 1957, 1959).

Broadhurst (1957) examined the effect of acute oxygen deprivation in the successful discrimination learning in an underwater maze for emotional and non-emotional rats. Among the various explanations of the Yerkes-Dodson effect was that the range of cue utilization narrows with arousal (Easterbrook, 1959). That is, at low levels of arousal too many extraneous cues are processed, at very high levels of arousal, not enough critical cues are processed. The Goldilocks principle seemed to apply to cognitive performance as well as preferential choice.

Eysenck (1967) reviewed a number of studies which showed patterns of extraversion on performance that were similar to those that used experimental manipulations such as time stress, noise stress or sleep deprivation. The similarity of the effects of extraversion on performance to these putative arousal effects had been noticed by those working in the classical experimental tradition at the Medical Research Council's Applied Psychology Unit at Cambridge (e.g., Colquhoun \& Corcoran, 1964; Corcoran, 1965; Davies \& Hockey, 1966). Several of these researchers then used extraversion as a subject variable in order to extend the range of arousal. Unfortunately, these were mainly studies that were consistent with the arousal, inverted U hypothesis, as were many alternative results. In fact, in a 2 levels of experimental arousal x 2 levels of introversion/extraversion x 2 levels of task difficulty (e.g., Davies \& Hockey, 1966) $71 \%$ of possible outcomes would have been supportive. (See Revelle \& Anderson, 1992, for a 
discussion of the problem of the flexible use of multiple partial orders to fit many basic experimental tests of arousal.)

In a study with three levels of presumed increasing arousal (no time pressure, time pressure plus a placebo, time pressure plus $200 \mathrm{mg}$ of caffeine) and three levels (introverts-ambivertsextraverts were formed by cutting the introversion-extraversion dimension $)^{2}$, we found that while introverts performed best on a complex cognitive task (a practice test similar to the Graduate Record Exam - GRE) and extraverts the worst, with caffeine and time pressure these results were reversed (Revelle, Amaral \& Turriff, 1976). Extraversion was measured with the Eysenck Personality Inventory (Eysenck \& Eysenck, 1964).

In a subsequent replication and extension of this study Gilliland (1976) dosed subjects by body weight $(0,2$ and $4 \mathrm{mg} / \mathrm{kg})$ and measured extraversion using the Eysenck Personality Questionnaire (Eysenck \& Eysenck, 1975) for all of his subjects and the EPI (Eysenck \& Eysenck, 1964) for about $75 \%$ of them. While the results based upon the EPQ did not replicate the Revelle et al. (1976) results (Gilliland, 1976), those using the EPI did (Gilliland, 1980). The difference between these sets of results could be shown to be the difference in the measurement of extraversion. Revelle et al. (1976) had used the EPI, Gilliland (1976) the EPQ. Although these two measures of extraversion correlated at their internal consistency estimates of reliability, the factor structure was clearly different (Rocklin \& Revelle, 1981). The EPI extraversion was a mix of sociability and impulsivity items, while the EPQ extraversion was predominantly sociability.

In a frustrating series of studies that followed Gilliland's dissertation, some of the experiments showed the expected extraversion by caffeine interaction (introverts being hurt by caffeine, extraverts helped by the increased arousal) but others showed the opposite results. These findings were clarified when we took the implications of the diurnal rhythm study of 
Blake (1967) into account, and analyzed the morning and evening results separately. In reviewing the seven studies we had done, we found that in every morning study, the performance of low impulsives was hindered but that of high impulsives facilitated by the administration of caffeine. We also observed that the effects were reliable when measuring impulsivity, but not when measuring sociability (Revelle, Humphreys, Simon \& Gilliland, 1980).

Based on our experimental distinction between impulsivity and sociability, as well as psychometric evidence that extraversion was a 'shotgun wedding' of two loosely related traits (Guilford, 1975) Campbell (1983) reanalyzed the results of Campbell and Hawley (1982) and found that the results were much more consistent for the impulsivity items of the EPI rather than the sociability items. Similar analyses were reported by Frcka and Martin (1987) who considered alternative meanings of extraversion as it related to the sub-components of impulsivity and sociability. The debate about the proper measurement of extraversion was between Eysenck (1977) and Frcka and Martin (1987) who tried to integrate psychometrics with experimental findings, with Guilford $(1975,1977)$ who relied on psychometric evidence.

In a series of experiments, we investigated the reliable but complex interactive patterns of impulsivity, time of day, caffeine, and task difficulty (Anderson, Revelle \& Lynch, 1989; Anderson \& Revelle, 1982, 1983, 1994). The unifying theme of these studies, consistent with the original hypothesis of Eysenck, was that arousal had an inverted U relationship with performance, this relationship varied by task difficulty, and that caffeine was a stimulant. The interaction of time of day and impulsivity in these studies was consistent with they hypothesis of diurnal phase differences in arousal as a function of impulsivity. Our findings suggested that impulsivity did not show trait differences in arousal but rather varied depending upon the time of day. Intriguingly enough, in hindsight the original study by Colquhoun \& 
Corcoran (1964) could be interpreted as consistent with these results and as showing a time of day decrement for introverts, not due to over-arousal, but rather to introverts being less aroused in the evening. Our findings led to a model of how several dimensions of personality (impulsivity, anxiety, and need for achievement) combined with situational manipulations (caffeine, time of day, success/failure feedback, and monetary incentives) to affect two motivational states (effort and arousal) which in turn affected three aspects of cognition (short term memory, long term memory, and sustained attention) (Humphreys \& Revelle, 1984; Revelle, 1993).

This model decomposed the inverted $\mathrm{U}$ and task difficulty components of the YerkesDodson effect in terms of two monotonic effects of arousal: one increasing, one decreasing. This approach followed the dictum that any function where the first or second derivative changes sign should be decomposed into two competing monotonic functions (Coombs \& Avrunin, 1977), or the suggestion by Berlyne (1973) that two antagonistic systems can lead to an inverted U relationship. Evidence for the "Yerkes-Dodson-Law" (Teigen, 1994; Yerkes \& Dodson, 1908) and how it related more to impulsivity than to sociability was shown in an elegant within subject study by Anderson (1994).

Lest we seem to claim superiority for impulsivity as a basis for theory development, it is important to comment that impulsivity is probably some strange amalgam of approach, avoidance, and restraint (Revelle, 1997). "There is no true impulsivity, and the best way of looking at impulsive behaviour in a causal manner would be by referring it to $\mathrm{P}, \mathrm{E}$, and $\mathrm{N}$ in combination" (Eysenck \& Eysenck, 1985, p. 355). (Where P, E, and N refer to the dimensions of psychoticism, extraversion, neuroticism, respectively.) Like most personality traits, impulsivity exhibits an interesting blend of biological correlates, behavioural tendencies, and cognitive 
control processes. What leads one to be impulsive in one situation might not be the same mechanism that leads to preferential choice of situations putting one at risk for impulsive behaviour (Revelle, 1987, 1997).

\section{Personality and Individual Differences: A natural science approach}

The most outstanding characteristic of Eysenck's research career was his dedication to paradigmatic research and his openness to competing theoretical claims. This was superbly exemplified in Eysenck and Eysenck (1985) which reviews findings associated with the Eysenck tradition, as well as those critical of that work. This is partly a discussion of Eysenck's philosophy of science and the growth of a scientific theory. The process of science is seen as going from hunches, to hypotheses, to theories, to laws. Pre-theoretic speculations are first developed to incorporate the existing data and are subject to confirmation. Only when the hypotheses are clear cut are they open to disconfirming studies. But such studies are not definitive, but progress from troubling to leading to revisions of theory. For good theories are broad ranging and should only be replaced with better ones. This book is well worth reading, even 30 years after publication. In Eysenck and Eysenck (1985) the critical findings supporting and disagreeing with the basic theory are carefully considered and partly integrated into the model. The conclusion of the chapter discussing extraversion, arousal and performance is most telling:

"In sum, the simple notion that introverts have a chronically higher level of cortical arousal that extraverts has proved extraordinarily successful in accounting for an enormous variety of findings. Not surprisingly, there are cases in which the theory's fit to the data is imperfect, and a more complex formulation may be needed at some point. However, the general 
rule in science is that a theory is usually discarded only when a superior theory replaces it, and this has not happened so far.” (Eysenck \& Eysenck, 1985, p. 288)

Such a competing theory was that developed by Eysenck's friend and colleague, Jeffrey Gray (Gray, 1970, 1981, 1991; Gray \& McNaughton, 2000). As a nice example of Eysenck's openness to theoretical challenges, at the first meeting of ISSID in 1983, Eysenck introduced Gray by first criticizing Gray's alternative model, and then announced how happy he was that Jeffrey would replace him at the Maudsley. This was in the best tradition of these two scientists: trying to better develop theoretical explanations of the complex set of data that had come from years of paradigmatic research.

A thoughtful comparison of these two theories (Matthews \& Gilliland, 1999) ${ }^{3}$ concluded that neither is completely supported by the available data. This review was very thorough and included psychophysiological evidence from both the central (EEG) and peripheral (e.g., Skin Conductance) nervous systems, mood and subjective states, conditioning, and attention and performance. Their conclusion is that both theories received generally supportive evidence but are too limited in their generalization to the complexity of human thought and behaviour. In particular, the one to one mapping between neural systems and personality traits of both theories seems overly optimistic and is probably too simplistic and we need to include cognitive constructs in our explanations of behaviour.

Besides emphasizing PEN as dimensions of personality, Eysenck had a long history of including cognitive ability as an important aspect of human personality (Eysenck, 1982). Thus, a chapter in Eysenck and Eysenck (1985) is devoted to this important dimension. Eysenck's influence on the field was seen in the willingness of members of ISSID and the pages of PAID to 
consider individual differences in ability at the same time as other dimensions of personality were discussed. This differs from the standard personality researcher in the US who is not as well informed about differences in cognitive ability as their European counterparts.

\section{The Influence of Eysenck on current personality theory}

Although clearly Eysenck's contributions range far beyond his PEN theory and models of intelligence, he is probably known to personality theorists for his work on extraversion. It is hard to believe that even by the late 1960's Eysenck could claim to have read most of the literature on extraversion (Eysenck, 1971). For in the last few years, that literature has exploded. Josh Wilt and I wrote a review chapter in 2009 with citations to 143 of the major papers (Wilt \& Revelle, 2009) but when we wrote an update to that chapter (Wilt \& Revelle, 2016) we needed to add 76 new citations to the newest literature. A quick search of Google Scholar shows more than 106,000 citations to extraversion, 30,600 to 'Extraversion and Eysenck' and more than 8,000 to 'introversion-extraversion'. But it is not just extraversion: there are 9,250 citations to 'Personality Theory' and Eysenck, with almost 1,000 just in the past year.

A major problem in personality is measurement. This is particularly troublesome when reviewing extraversion. Different researcher groups use different scales and each has a unique emphasis. Extraversion is variously seen as primarily social dominance, energy, positive affect, sociability, and impulsivity. Although measures of extraversion may correlate highly, it is the pattern of what the scales do not correlate with that more properly defines them. For although two scales correlate .7 with alpha estimates of internal consistency of .7, that does not mean they are measuring the same construct: it possible for the underlying measures to be mixes of various lower level factors. EPI and EPQ extraversion differ in their item content with respect to impulsivity (Rocklin \& Revelle, 1981) and neither scale correlates very highly with positive 
affect. Extraversion as measured by the NEO-PI-R (Costa \& McCrae, 1992), however, has a much higher correlation with positive affect. In the three dimensional model of Tellegen \& Waller (2008), extraversion is equated with positive emotionality, and neuroticism with negative emotionality. Wilt (2014) (see also Wilt \& Revelle, 2015) examined items of the various inventories meant to assess the Big 5 and categorized them in terms of how much the items reflected affective, behavioural, cognitive, or desire content (the ABCD's of personality). This approach is useful when trying to understand the differences between various scales purported to measure the same construct (e.g., extraversion).

Eysenck's influence extended outside of those who studied extraversion or neuroticism. In a very thoughtful comparison of the theoretical contributions of John Atkinson (e.g., Atkinson, 1957, 1974; Atkinson \& Raynor, 1974), Kenneth Spence (e.g., Spence, Farber \& McFann, 1956; Spence, 1964) and Hans Eysenck, Alktinson's student Nathan Brody concluded that the theoretical contributions of Eysenck were the most important contribution to personality theory (Brody, 1972). More recently, achievement motivation theorists (Elliot \& Thrash, 2002, 2010; Elliot, Sheldon \& Church, 1997) have tried to integrate the approach/avoidance dimensions of Atkinson with those of Eysenck (1967) and of Gray (1991). Taking biological sensitivities (temperamental traits) and integrating them with environmental cues for approach and avoidance has great potential for integrating trait psychology with current motivational theory.

Perhaps the greatest continuing contribution of Eysenck's theories may be found in the various studies included under the rubric of Reinforcement Sensitivity Theory (Corr, 2008; Gray \& McNaughton, 2000; Smillie et al., 2006, 2011). Although based upon Gray's thinking about the biological bases of personality, some of the studies have clarified the relationship of 
extraversion to positive affect (Smillie, 2013; Smillie, Cooper, Wilt \& Revelle, 2012) whereas others have related biological principles to motivation theory (Corr et al., 2013). Still others have emphasized the measurement of RST constructs (Corr, 2016; Corr \& Cooper, 2016;

Jackson, 2009; Reuter, Cooper, Smillie, Markett \& Montag, 2015; Smederevac, Mitrović, Čolović \& Nikolašević, 2014). In addition, Eysenck’s theories of temperament, blended with Pavlov's typologies of the nervous system (Gray, 1964; Nebylitsyn \& Gray, 1964) have been expanded by Jan Strelau (1987, 1997, 1998) and Strelau \& Eysenck (1987).

The contributions of Eysenck to current personality theory live on in the journals and societies that he founded, the many students who trained in his labs, the many researchers who were inspired by his programmatic research endeavors, and the continuing research tradition on broad, causal theories of personality and individual differences that he espoused.

\section{A personal note}

I first came across Eysenck's books in 1966 while my wife and I were serving as Peace Corps Volunteers in a small village in Sarawak, Malaysia, 60 miles up the Limbag river from Brunei. Whenever we had to go through Brunei to get to the rest of Sarawak, we tended to stop off at the one book store in town to find something new to read. The only serious psychology books at the Brunei bookstore were three paperbacks by Eysenck: Uses and Abuses of Psychology (Eysenck, 1953), Sense and Nonsense in Psychology (Eysenck, 1964) and Fact and Fiction in Psychology (Eysenck, 1965). Like many students of my generation, these were the first hints that one could integrate mathematics and science in the study of personality. I was hooked and became a personality psychologist. Fifty years later, I have no regrets. 


\section{Acknowledgement}

Preparation of this manuscript was funded in part by grant SMA-1419324 from the National Science Foundation 
References

Allport, G. W. (1937). Personality: A Psychological Interpretation. New York: H. Holt and Company.

Allport, G. W. \& Odbert, H. S. (1936). Trait-names: a psycho-lexical study. Psychological Monographs, 47(211).

Anderson, K. J. (1994). Impulsivity, caffeine, and task difficulty: a within-subjects test of the Yerkes-Dodson law. Personality and Individual Differences, 16, 813-829.

Anderson, K. J. \& Revelle, W. (1982). Impulsivity, caffeine, and proofreading: a test of the Easterbrook hypothesis. Journal of Experimental Psychology: Human Perception and Performance, 8, 614-624.

Anderson, K. J. \& Revelle, W. (1983). The interactive effects of caffeine, impulsivity and task demands on a visual search task. Personality and Individual Differences, 4, 127-134.

Anderson, K. J. \& Revelle, W. (1994). Impulsivity and time of day: is rate of change in arousal a function of impulsivity? Journal of Personality and Social Psychology, 67, 334-344.

Anderson, K. J., Revelle, W. \& Lynch, M. J. (1989). Caffeine, impulsivity, and memory scanning: a comparison of two explanations for the Yerkes-Dodson Effect. Motivation and Emotion, 13, 1-20.

Ashton, M. C. \& Lee, K. (2005a). A defence of the lexical approach to the study of personality structure. European Journal of Personality, 19, 5-24.

Ashton, M. C. \& Lee, K. (2005b). Honesty-humility, the big five, and the five-factor model. Journal of Personality, 73, 1321-1353.

Ashton, M. C., Lee, K. \& Goldberg, L. R. (2007). The IPIP-HEXACO scales: an alternative, 
public-domain measure of the personality constructs in the HEXACO model. Personality and Individual Differences, 42, 1515-1526.

Atkinson, J. W. (1957). Motivational determinants of risk-taking behavior. Psychological Review, 64, 359-372.

Atkinson, J. W. (1974). Strength of motivation and efficiency of performance. In J. W. Atkinson \& J. O. Raynor (Eds.), Motivation and Achievement (pp. 117-142). New York: Winston (Halsted Press/Wiley).

Atkinson, J. W. \& Raynor, J. O. (Eds.). (1974). Motivation and Achievement. New York: Winston (Halsted Press/Wiley).

Bartol, C. R. (1975). The effects of chlorpromazine and dextroamphetamine sulfate on the visual stimulation preference of extraverts and introverts. Psychophysiology, 12, 25-29.

Berlyne, D. E. (1960). Conflict, Arousal, and Curiosity. McGraw-Hill series in psychology. New York: McGraw-Hill.

Berlyne, D. E. (1973). The vicissitudes of aplopathematic and thelematoscopic pneumatology (or the hydrography of hedonism). In D. Berlyne \& K. B. Madsen (Eds.), Pleasure, Reward, Preference: Their Nature, Determinants, and Role in Behavior (pp. 1-33). New York and London: Academic Press.

Blake, M. J. (1967). Relationship between circadian rhythm of body temperature and introversion-extraversion. Nature, 215, 896-897.

Bouchard, T. J. (1994). Genes, environment, and personality. Science, 264, 1700-1701.

Broadbent, D. (1971). Decision and Stress. London: Academic Press.

Broadhurst, P. L. (1957). Emotionality and the Yerkes-Dodson Law. Journal of Experimental Psychology, 54, 345-352. 
Broadhurst, P. L. (1959). The interaction of task difficulty and motivation: the Yerkes-Dodson law revived. Acta Psychologica, 16, 321-338.

Brody, N. (1972). Personality: Research and Theory. Academic Press.

Browne, M. W. (2001). An overview of analytic rotation in exploratory factor analysis. Multivariate Behavioral Research, 36, 111-150.

Campbell, J. B. (1983). Differential relationships of extraversion, impulsivity, and sociability to study habits. Journal of Research in Personality, 17, 308-314.

Campbell, J. B. \& Hawley, C. W. (1982). Study habits and Eysenck's theory of extraversionintroversion. Journal of Research in Personality, 16, 139-146.

Carothers, B. J. \& Reis, H. T. (2013). Men and women are from earth: examining the latent structure of gender. Journal of Personality and Social Psychology, 104, 385-407.

Carroll, J. (1953). An analytical solution for approximating simple structure in factor analysis. Psychometrika, 18, 23-38.

Cattell, R. B. (1943). The description of personality. I. Foundations of trait measurement. Psychological Review, 50, 559-594.

Cattell, R. B. (1946a). Description and Measurement of Personality. Oxford, England: World Book Company.

Cattell, R. B. (1946b). Personality structure and measurement. I. The operational determination of trait unities. British Journal of Psychology, 36, 88-102.

Cattell, R. B. (1946c). Personality structure and measurement. II. The determination and utility of trait modality. British Journal of Psychology, 36, 159-174.

Cattell, R. B. (1963). Theory of fluid and crystallized intelligence: a critical experiment. Journal of Educational Psychology, 54, 1-22. 
Cattell, R. B. (1966a). The data box: its ordering of total resources in terms of possible relational systems. In R. B. Cattell (Ed.), Handbook of Multivariate Experimental Psychology (pp. 67-128). Chicago: Rand-McNally.

Cattell, R. B. (1966b). The scree test for the number of factors. Multivariate Behavioral Research, 1, 245-276.

Cattell, R. B. (1978). The Scientific Use of Factor Analysis. New York: Plenum Press.

Claridge, G. (1967). Personality and Arousal. Pergamon Press.

Claridge, G. S. \& Herrington, R. N. (1960). Sedation threshold, personality, and the theory of neurosis. The British Journal of Psychiatry, 106, 1568-1583.

Cole, D. A. (2004). Taxometrics in psychopathology research: an introduction to some of the procedures and related methodological issues. Journal of Abnormal Psychology, 113, 3 9.

Colquhoun, W. \& Corcoran, D. W. (1964). The effects of time of day and social isolation on the relationship between temperament and performance. British Journal of Social and Clinical Psychology, 3, 226-231.

Coombs, C. H. \& Avrunin, G. S. (1977). Single-peaked functions and the theory of preference. Psychological Review, 84, $216-230$.

Corcoran, D. W. J. (1964). The relation between introversion and salivation. The American Journal of Psychology, 77, 298-300.

Corcoran, D. W. J. (1965). Personality and the inverted-U relation. British Journal of Psychology, 56, 267-273.

Corr, P. J. (Ed.). (2008). The Reinforcement Sensitivity Theory of Personality. Cambridge: Cambridge University Press. 
Corr, P. J. (2016). Reinforcement sensitivity theory of personality questionnaires: structural survey with recommendations. Personality and Individual Differences, 89, 60-64.

Corr, P. J. \& Cooper, A. (2016). The reinforcement sensitivity theory of personality questionnaire (RST-PQ): development and validation. Psychological Assessment, in press.

Corr, P. J., DeYoung, C. G. \& McNaughton, N. (2013). Motivation and personality: a neuropsychological perspective. Social and Personality Psychology Compass, 7, 158175.

Costa, P. T. \& McCrae, R. R. (1992). Four ways five factors are basic. Personality and Individual Differences, 13, 653-665.

Cronbach, L. J. (1957). The two disciplines of scientific psychology. American Psychologist, $12,671-684$.

Davies, D. \& Hockey, G. (1966). The effects of noise and doubling the signal frequency on individual differences in visual vigilance performance. British Journal of Psychology, 57, $381-389$.

Duffy, E. . (1962). Activation and Behavior. Oxford, England: Wiley.

Duffy, E. (1951). The concept of energy mobilization. Psychological Review, 58, 30-40.

Easterbrook, J. (1959). The effect of emotion on cue utilization and the organization of behavior. Psychological Review, 66, 183-20.

Elliot, A. J., Sheldon, K. M. \& Church, M. A. (1997). Avoidance personal goals and subjective well-being. Personality and Social Psychology Bulletin, 23, 915-927.

Elliot, A. J. \& Thrash, T. M. (2002). Approach-avoidance motivation in personality: approachavoidance temperaments and goals. Journal of Personality and Social Psychology, 82, 
804-818.

Elliot, A. J. \& Thrash, T. M. (2010). Approach and avoidance temperament as basic dimensions of personality. Journal of Personality, 78, 865-906.

Elliott, C. D. (1971). Noise tolerance and extraversion in children. British Journal of Psychology, 62, 375-380.

Eysenck, H. (1984). Meta-analysis: an abuse of research integration. The Journal of Special Education, 18, 41-59.

Eysenck, H. J. (1944). Types of personality: a factorial study of seven hundred neurotics. The British Journal of Psychiatry, 90, 851-861.

Eysenck, H. J. (1952). The Scientific Study of Personality. London: Routledge \& K. Paul.

Eysenck, H. J. (1953). Uses and Abuses of Psychology. London, Baltimore: Penguin Books.

Eysenck, H. J. (1957). The Dynamics of Anxiety and Hysteria: An Experimental Application of Modern Learning Theory to Psychiatry. Oxford, England: Praeger.

Eysenck, H. J. (1959). Manual for the Maudsley Personality Inventory. London: University of London Press.

Eysenck, H. J. (1964). Sense and Nonsense in Psychology. Baltimore: Penguin Books.

Eysenck, H. J. (1965). Fact and Fiction in Psychology. Baltimore: Penguin Books.

Eysenck, H. J. (1966). Personality and experimental psychology. Bulletin of the British Psychological Society, 19, 1-28.

Eysenck, H. J. (1967). The Biological Basis of Personality. Springfield: Thomas.

Eysenck, H. J. (1971). Readings in Extraversion-introversion: Theoretical and Methodological Issues, volume 1. London: Staples.

Eysenck, H. J. (1977). Personality and factor analysis: a reply to Guilford. Psychological 
Bulletin, 84, 405-411.

Eysenck, H. J. (1982). A Model for Intelligence. Berlin: Springer Science \& Business Media. Eysenck, H. J. (1988). The growth of a unified scientific psychology. In A. Staats \& L. Mos (Eds.), Annals of Theoretical Psychology (volume 5) (pp. 91-113). Springer US.

Eysenck, H. J. (1997). Personality and experimental psychology: the unification of psychology and the possibility of a paradigm. Journal of Personality and Social Psychology, 73, $1224-1237$.

Eysenck, H. J. \& Eysenck, M. W. (1985). Personality and Individual Differences: A Natural Science Approach. New York: Plenum.

Eysenck, H. J. \& Eysenck, S. B. G. (1964). Eysenck Personality Inventory. San Diego, California: Educational and Industrial Testing Service.

Eysenck, H. J. \& Eysenck, S. B. G. (1975). Manual of the Eysenck Personality Questionnaire (Junior and Adult). Kent, UK: Hodder \& Stoughton.

Eysenck, H. J. (1947). Dimensions of Personality. London: Routledge \& Kegan Paul.

Farley, F. \& Farley, S. V. (1967). Extraversion and stimulus-seeking motivation. Journal of Consulting Psychology, 31, 215 - 216.

Farley, F. H. \& Farley, S. V. (1970). Impulsiveness, sociability, and the preference for varied experience. Perceptual and motor skills, 31, 47-50.

Frcka, G. \& Martin, I. (1987). Is there — or is there not—an influence of impulsiveness on classical eyelid conditioning? Personality and Individual Differences, 8, 241-252.

Gale, A. (1981). EEG studies of extraversion-introversion: what's the next step? In R. Lynn (Ed.), Dimensions of Personality: Papers in Honour of H. J. Eysenck (pp. 181-207). Oxford: Pergamon Press. 
Galton, F. (1884). Measurement of character. Fortnightly Review, 36, 179-185.

Gilliland, K. (1976). The Interactive Effect of Introversion-extroversion with Caffeine Induced Arousal on Verbal Performance. PhD thesis, Northwestern University.

Gilliland, K. (1980). The interactive effect of introversion-extraversion with caffeine induced arousal on verbal performance. Journal of Research in Personality, 14, 482 - 492.

Goldberg, L. R. (1992). The development of markers for the big-five factor structure. Psychological Assessment, 4, 26-42.

Gray, J. A. (1964). Pavlov's typology: Recent Theoretical and Experimental Developments from the laboratory of B.M. Teplov. New York: Pergamon Press, MacMillan Company.

Gray, J. A. (1970). The psychophysiological basis of introversion-extraversion. Behaviour Research and Therapy, 8, 249-266.

Gray, J. A. (1981). A critique of Eysenck's theory of personality. In H. J. Eysenck (Ed.), A Model for Personality (pp. 246-277). Berlin: Springer.

Gray, J. A. (1991). The neuropsychology of temperament. In J. Strelau \& A. Angleitner (Eds.), Explorations in Temperament: International Perspectives on Theory and Measurement (pp. 105-128). New York, NY: Plenum Press.

Gray, J. A. \& McNaughton, N. (2000). The Neuropsychology of Anxiety: An Enquiry into the Functions of the Septo-hippocampal System ( ${ }^{\text {nd }}$ Ed.). Oxford: Oxford University Press. Grayson, D. A. (1987). Can categorical and dimensional views of psychiatric illness be distinguished? The British Journal of Psychiatry, 151, 355-361.

Guilford, J. P. (1975). Factors and factors of personality. Psychological Bulletin, 82, 802-814. Guilford, J. P. (1977). Will the real factor of extraversion-introversion please stand up? A reply to Eysenck. Psychological Bulletin, 84, 412-416. 
Haslam, D. R. (1967). Individual differences in pain threshold and level of arousal. British Journal of Psychology, 58, 139-142.

Hebb, D. O. (1955). Drives and the c. n. s. (conceptual nervous system). Psychological Review, $62,243-254$

Hofstee, W. K., de Raad, B. \& Goldberg, L. R. (1992). Integration of the big five and circumplex approaches to trait structure. Journal of Personality and Social Psychology, $63,146-163$.

Hofstee, W. K. B., Kiers, H. A., de Raad, B., Goldberg, L. R. \& Ostendorf, F. (1997). A comparison of big-five structures of personality traits in Dutch, English, and German. European Journal of Personality, 11, 15-31.

Horn, J. L. \& Cattell, R. B. (1966). Refinement and test of the theory of fluid and crystallized general intelligences. Journal of Educational Psychology, 57, 25-270.

Hull, C. L. (1943). Principles of Behavior: An Introduction to Behavior Theory. Oxford, England: Appleton-Century.

Hull, C. L. (1952). A Behavior System. New Haven: Yale University Press.

Humphreys, M. S. \& Revelle, W. (1984). Personality, motivation, and performance: a theory of the relationship between individual differences and information processing. Psychological Review, 91, 153-184.

Jackson, C. J. (2009). Jackson-5 scales of revised reinforcement sensitivity theory (r-RST) and their application to dysfunctional real world outcomes. Journal of Research in Personality, 43, $556-569$.

Kaiser, H. (1958). The varimax criterion for analytic rotation in factor analysis. Psychometrika, 23, 187-200. 
Krueger, R. F. (2002). Psychometric perspectives on comorbidity. In J. E. Helzer \& J. J. Hudziak (Eds.), Defining Psychopathology in the 21st Century: DSM-V and Beyond (pp. 41-54). Washington, DC: American Psychiatric Publishing.

Krueger, R. F. \& Finger, M. S. (2001). Using item response theory to understand comorbidity among anxiety and unipolar mood disorders. Psychological Assessment, 13, 140-151.

Krueger, R. F. \& Markon, K. E. (2006). Understanding psychopathology: melding behavior genetics, personality, and quantitative psychology to develop an empirically based model. Current Directions in Psychological Science, 15, 113-117.

Lacey, J. L. (1967). Somatic response patterning: Some revisions of activation theory. In M. H. A. R. Trumbell (Ed.), Psychological Stress (pp. 14-37). New York: Appleton-CenturyCrofts.

Levey, A. \& Martin, I. (1981). Personality and conditioning. In H. J. Eysenck (Ed.), A Model for Personality (pp. 123-168). Springer Berlin Heidelberg.

Lindsley, D. (1951). Emotion. In S. Stevens (Ed.), Handbook of Experimental Psychology (pp. 473-516). New York: Wiley.

Loehlin, J. C. (1965). A heredity-environment analysis of personality inventory data. In S. G. Vandenberg (Ed.), Methods and Goals in Human Behavior Genetics (pp. 163-168). New York and London: Academic Press.

Loehlin, J. C. (1992). Genes and Environment in Personality Development. Thousand Oaks, CA, US: Sage.

Malmo, R. B. (1959). Activation: A neuropsychological dimension. Psychological review, 66, $367-386$.

Markon, K. E., Krueger, R. F. \& Watson, D. (2005). Delineating the structure of normal and 
abnormal personality: An integrative hierarchical approach. Journal of Personality and Social Psychology, 88, 139-157.

Matthews, G. \& Gilliland, K. (1999). The personality theories of H. J. Eysenck and J. A. Gray: a comparative review. Personality and Individual Differences, 26, 583-626.

McAdams, D. P. (2008). Personal narratives and the life story. In O. P. John, R. W. Robins \& L. A. Pervin (Eds.), Handbook of Personality: Theory and Research (3 ed.). (pp. $242-$ 262). New York, NY: Guilford Press.

McCrae, R. R. \& Costa, P. T. (2008). Empirical and theoretical status of the five-factor model of personality traits. In G. J. Boyle, G. Matthews \& D. H. Saklofske (Eds.), The Sage Handbook of Personality Theory and Assessment, volume 1 (pp. 273-294). Los Angeles, CA: Sage Los Angeles, CA.

McGue, M. \& Bouchard, Thomas J. (1998). Genetic and environmental influences on human behavioral differences. Annual Review of Neuroscience, 21, 1-24.

Meehl, P. E. (1992). Factors and taxa, traits and types, differences of degree and differences in kind. Journal of Personality, 60, 117-174.

Nebylitsyn, V. \& Gray, J. A. (1964). Biological Bases of Individual Behavior. New York and London: Academic Press.

Norman, W. T. (1963). Toward an adequate taxonomy of personality attributes: replicated factors structure in peer nomination personality ratings. Journal of Abnormal and Social Psychology, 66, 574-583.

Norman, W. T. (1967). 2800 Personality Trait Descriptors: Normative Operating Characteristics for a University Population. Technical report, University of Michigan.

Petrie, A., Collins, W. \& Solomon, P. (1960). The tolerance for pain and for sensory 
deprivation. The American Journal of Psychology, 73, 80-90.

Reuter, M., Cooper, A. J., Smillie, L. D., Markett, S. \& Montag, C. (2015). A new measurement for the revised reinforcement sensitivity theory: psychometric criteria and genetic validation. Frontiers in Systems Neuroscience, 9(38).

Revelle, W. (1983). Factors are fictions, and other comments on individuality theory. Journal of Personality, 51, 707-714.

Revelle, W. (1987). Personality and motivation: sources of inefficiency in cognitive performance. Journal of Research in Personality, 21, 436 - 452.

Revelle, W. (1993). Individual differences in personality and motivation: 'non-cognitive' determinants of cognitive performance. In A. Baddeley \& L. Weiskrantz (Eds.), Attention: Selection, Awareness and Control: A Tribute to Donald Broadbent (pp. 346373). Oxford: Oxford University Press.

Revelle, W. (1997). Extraversion and impulsivity: The lost dimension? In H. Nyborg (Ed.), The Scientific Study of Human Nature: Tribute to Hans J. Eysenck at Eighty (pp. 189212). Amsterdam, Netherlands: Pergamon/Elsevier Science Inc.

Revelle, W., Amaral, P. \& Turriff, S. (1976). Introversion-extraversion, time stress, and caffeine: effect on verbal performance. Science, 192, 149-150.

Revelle, W. \& Anderson, K. J. (1992). Models for the testing of theory. In A. Gale \& M. Eysenck (Eds.), Handbook of Individual Differences: Biological Perspectives (pp. 81113). Chichester: John Wiley and Sons.

Revelle, W., Humphreys, M. S., Simon, L. \& Gilliland, K. (1980). The interactive effect of personality, time of day and caffeine: a test of the arousal model. Journal of Experimental Psychology: General, 109, 1-31. 
Revelle, W., Wilt, J. \& Condon, D. (2011). Individual differences and differential psychology: a brief history and prospect. In T. Chamorro-Premuzic, A. Furnham \& S. von Stumm (Eds.), Handbook of Individual Differences (pp. 3-38). Oxford: Wiley-Blackwell.

Rocklin, T. \& Revelle, W. (1981). The measurement of extraversion: a comparison of the Eysenck Personality Inventory and the Eysenck Personality Questionnaire. British Journal of Social Psychology, 20, 279-284.

Ruscio, J. \& Ruscio, A. M. (2000). Informing the continuity controversy: a taxometric analysis of depression. Journal of abnormal psychology, 109, 473-487.

Ruscio, J. \& Ruscio, A. M. (2008). Categories and dimensions: advancing psychological science through the study of latent structure. Current Directions in Psychological Science, 17, 203-207.

Saucier, G. (2009). What are the most important dimensions of personality? evidence from studies of descriptors in diverse languages. Social and Personality Psychology Compass, $3,620-637$.

Shigehisa, T. \& Symons, J. R. (1973). Effect of intensity of visual stimulation on auditory sensitivity in relation to personality. British Journal of Psychology, 64, 205-213.

Smederevac, S., Mitrović, D., Čolović, P. \& Nikolašević, Ž. (2014). Validation of the measure of revised reinforcement sensitivity theory constructs. Journal of Individual Differences, $35,12-21$.

Smillie, L. D. (2013). Why does it feel good to act like an extravert? Social and Personality Psychology Compass, 7, 878-887.

Smillie, L. D., Cooper, A., Wilt, J. \& Revelle, W. (2012). Do extraverts get more bang for the buck? refining the affective-reactivity hypothesis of extraversion. Journal of Personality 
and Social Psychology, 103, 306-326.

Smillie, L. D., Loxton, N. J. \& Avery, R. E. (2011). Reinforcement sensitivity theory, research, applications and future. In T. Chamorro-Premuzic, A. F. Furnham \& S. von Stumm (Eds.), Handbook of Individual Differences (pp. 101-131). Wiley-Blackwell.

Smillie, L. D., Pickering, A. D. \& Jackson, C. J. (2006). The new reinforcement sensitivity theory: implications for personality measurement. Personality and Social Psychology Review, 10, 320-335.

Spearman, C. (1904). "General Intelligence," objectively determined and measured. American Journal of Psychology, 15, 201-292.

Spence, K., Farber, I. \& McFann, H. (1956). The relation of anxiety (drive) level to performance in competitional and non-competitional paired-associates learning. Journal of Experimental Psychology, 52, 296-305.

Spence, K. W. (1964). Anxiety (drive) level and performance in eyelid conditioning. Psychological Bulletin, 61, 129-139.

Stelmack, R. M. (1990). Biological bases of extraversion: psychophysiological evidence. Journal of Personality, 58, $293-311$.

Stelmack, R. M. \& Wilson, K. G. (1982). Extraversion and the effects of frequency and intensity on the auditory brainstem evoked response. Personality and Individual Differences, 3, $373-380$.

Strelau, J. (1987). Emotion as a key concept in temperament research. Journal of Research in Personality, 21, 510-528.

Strelau, J. (1997). The contribution of Pavlov's typology of CNS properties to personality research. European Psychologist, 2, 125-138. 
Strelau, J. (1998). Temperament: A Psychological Perspective. New York, NY: Plenum Press.

Strelau, J. \& Eysenck, H. J. (1987). Personality Dimensions and Arousal. New York: Plenum Press.

Teigen, K. H. (1994). Yerkes-Dodson: a law for all seasons. Theory and Psychology, 4, 525547.

Tellegen, A., Lykken, D. T., Bouchard, T. J., Wilcox, K. J., Segal, N. L. \& Rich, S. (1988). Personality similarity in twins reared apart and together. Journal of Personality and Social Psychology, 54, 1031-1039.

Tellegen, A. \& Waller, N. G. (2008). Exploring personality through test construction: development of the Multidimensional Personality Questionnaire. The Sage Handbook of Personality Theory and Assessment, volume 2 (pp. 261-292). London: Sage.

Thayer, R. E. (1970). Activation states as assessed by verbal report and four psychophysiological variables. Psychophysiology, 7, 86-94.

Thayer, R. E. (1978). Toward a psychological theory of multidimensional activation (arousal). Motivation and Emotion, 2, 1-34.

Thurstone, L. L. (1933). The Theory of Multiple Factors. Ann Arbor, Michigan: Edwards Brothers.

Thurstone, L. L. (1935). The Vectors of Mind: Multiple-factor Analysis for the Isolation of Primary Traits. Chicago: University of Chicago Press.

Tupes, E. C. \& Christal, R. E. (1961). Recurrent Personality Factors based on Trait Ratings. Technical Report 61-97, USAF ASD Technical Report, Lackland Air Force Base. [Reprinted in Journal of Personality, 1992, 60, 225-251.]

Vale, J. \& Vale, C. (1969). Individual differences and general laws in psychology: a 
reconciliation. American Psychologist, 24, 1093-1108.

Waller, N. G. (2006). Carving nature at its joints: Paul Meehl's development of taxometrics. Journal of Abnormal Psychology, 115, 210 - 215.

Wilt, J. (2014). A New Form and Function for Personality. PhD thesis, Northwestern University.

Wilt, J. \& Revelle, W. (2009). Extraversion. In M. R. Leary \& R. H. Hoyle (Eds.), Handbook of Individual Differences in Social Behavior (pp. 27-45). New York: Guilford Press.

Wilt, J. \& Revelle, W. (2015). Affect, behavior, cognition and desire in the Big 5: an analysis of item content and structure. European Journal of Personality, 29, 478-497.

Wilt, J. \& Revelle, W. (2016). Extraversion. In T. Widiger (Ed.), The Oxford Handbook of the Five Factor Model. New York, N.Y.: Oxford University Press (in press).

Wundt, W. (1874). Grundzüge der physiologischen Psychologie (Principles of physiological psychology). Leipzig/Bristol: Wilhelm Engelmann/Thoemmes Press.

Wundt, W. (1897). Outlines of Psychology. Oxford, England: (translated by C. H. Judd) Engelmann.

Wundt, W. (1904). Principles of Physiological Psychology (Translated from the Fifth German Edition (1902) ed.). London: Swan Sonnenschein.

Yerkes, R. \& Dodson, J. (1908). The relation of strength of stimuli to rapidity of habitinformation. Journal of Comparative Neurology and Psychology, 18, 459-482. 


\section{Footnotes}

${ }^{1}$ Although most who study the dimension of introversion-extraversion think dimensionally, it is convenient and perhaps even conventional to refer to those at the more introverted end of the dimension as Introverts, and those at the more extraverted end as Extraverts. This should not be taken as implying a categorical typology, but is merely a linguistic shorthand.

${ }^{2}$ Were we to do this again, we would of course consider the linear and curvilinear interactions of the stress manipulations with extraversion as a continuous variable.

${ }^{3}$ The article was written at Eysenck's invitation but he died before it was finished. 